\title{
REAKSI DETAK JANTUNG MUSISI AMATIR DAN NON-AMATIR TERHADAP REPATOAR KLASIK BERTEMPO CEPAT DAN LAMBAT DAN MUSIK DANGDUT
}

\author{
Giovanli Lauren ${ }^{1}$, Tommy ${ }^{2}$ \\ Universitas Universal \\ 1'giovanlilauren@gmail.com, 2jakelee390_@gmail.com
}

\begin{abstract}
The importance of music in our daily life has given rise to an increased number of studies addressing the brain regions involved in its appreciation. Some of these studies controlled only for the familiarity of the stimuli, while others relied on pleasantness ratings, and others still on musical preferences. With a listening test and a recorded heart rate ratings experiment, we wished to clarify the role of familiarity in the brain correlates and the reaction of cardiovascular system of music appreciation by controlling, in the same study, for both familiarity and musical preferences. First, we conducted a listening test, in which participants rated the familiarity and liking of song excerpts from the classical repertoire and dangdut. Music the recorded fluctuation of heart rate gives us a slight information that there is/are factors that influence human biology system to respond music, aside from the natural respond of body to music in terms of experience that amateur and non-amateur musician had. Hence, familiarity seems to be a crucial factor in making the listeners emotionally engaged with music.
\end{abstract}

Keywords: Dangdut, Repertoire, Heart Rate, Recordings

\begin{abstract}
Abstrak: Pentingnya musik dalam kehidupan kita sehari-hari telah menyebabkan semakin banyak penelitian yang berhubungan dengan daerah otak yang terlibat dalam apresiasi mereka. Beberapa studi ini hanya mengendalikan intuisi rangsangan, sementara yang lain didasarkan pada basa-basi dan yang lain pada preferensi musik. Dengan tes mendengarkan dan percobaan tes detak jantung, kami ingin memperjelas peran keakraban dalam otak dan sistem kardiovaskuler dengan mengendalikan keakraban dan preferensi musik dalam penelitian yang sama. Pertama, kami melakukan tes mendengarkan di mana peserta mengevaluasi keakraban dan rasa repertoar klasik dan musik dangdut. Peningkatan dan penurunan detak jantung yang direkam memberikan kita informasi sementara bahwa ada faktor-faktor lain yang mempengaruhi biologis manusia terhadap respon musik selain respon alamiah tubuh terhadap musik dalam hal pengalaman yang dimiliki oleh musisi amatir dan non-amatir. Oleh karena itu, keakaraban, tampaknya menjadi faktor penting dalam membuat pendengar merasa secara emosional ke dalam musik.
\end{abstract}

Kata Kunci: Dangdut, Repertoar, Detak Jantung, Rekaman

\section{LATAR BELAKANG}

Dalam kehidupan saat ini, musik merupakan hal yang tidak terpisahkan dari kehidupan manusia. Bahkan telah diketahui bahwa musik sangat berpengaruh terhadap fisiologis dan psikologis manusia. Pengaruhnya yang signifikan ini membawa musik ke dalam bidang medis yang digunakan sebagai terapi. Hal ini dikarenakan adanya efek musik terhadap sistem-sistem tubuh manusia, seperti sistem kardiovaskuler, respirasi, pencernaan, dan kecerdasan manusia.

Heart rate (HR) misalnya, akan menanggapi variabel-variabel musik seperti frekuensi, tempo dan volume dan cenderung menjadi lebih cepat atau lebih lambat guna menyamai ritme suatu bunyi. Semakin cepat musiknya, semakin cepat HR; semakin lambat musiknya semakin lambat HR. (Campbell, 2001).

Musik juga mempengaruhi gelombang otak dengan memperlambat dan menyeimbangkan gelombang otak. Musik tertentu dapat meningkatkan kewaspadaan, memperkuat kesadaran atau bahkan mengakibatkan berubahnya keadaan sadar dan persepsi dimensidimensi lain. (Campbell, 2001). Adanya pengaruh musik terhadap otak juga mempengaruhi bagian memori pada otak, yang dimana musik dapat membangkitkan kembali memori-memori seseorang dan menciptakan emosi tertentu. Pengaruh musik terhadap fisiologis secara khusus 
juga sedikit tidaknya dipengaruhi oleh psikologis seseorang. Seperti pengalaman dan memori seseorang terhadap musik tertentu yang dapat memicu emosi pendengar dan kemudian mempengaruhi fisiologisnya. Sehingga hal ini tentu saja akan mempengaruhi fisiologis dan psikologis seorang musisi mengenai persepsinya terhadap sebuah lagu.

Di dalam lingkup dimana penelitian dilaksanakan yakni antara musisi non-amatir dan amatir yang sedang menempuh jenjang pendidikan sarjana dengan program studi seni musik yang menjurus pada musik klasik pada sebuah kampus yang terletak ditengah-tengah budaya melayu, sehingga kedua musisi non-amatir dan amatir tersebut sudah selayaknya mengenali musik klasik dan musik dangdut. Dengan perbedaan pengalaman jangka waktu bernusik yang menjadi dasar penelitian ini peneliti tertarik untuk melihat perubahan detak jantung antara musisi amatir dan non-amatir terhadap repatoar musik klasik dan musik dangdut diantara mahasiswa/i Prodi Seni Musik, Universitas Universal, Batam.

\section{KAJIAN TEORITIS}

Banyak penelitian yang sudah dilakukan mengenai hubungan antara musik dengan emosi yang berdampak pada reaksi biologis tubuh manusia. elah terbukti bahwa gairah dan suasana hati berbeda tetapi terkait aspek respon emosional (Husain et al., 2002). Meskipun penggunaan istilah-istilah ini bervariasi dalam literatur, suasana hati cenderung terkait dengan emosi yang relatif tahan lama (Sloboda dan Juslin, 2001), yang mungkin memiliki konsekuensi yang lebih besar untuk persepsi daripada untuk tindakan. Gairah biasanya merujuk pada tingkat aktivasi fisiologis atau intensitas respons emosional (Sloboda dan Juslin, 2001). Menurut hipotesis mood rangsangan, mendengarkan musik memengaruhi rangsangan dan suasana hati yang kemudian memengaruhi kinerja berbagai kemampuan kognitif. Pengaruh musik pada gairah dan suasana hati sudah dikenal. Orang sering mendengarkan musik untuk efek yang tepat ini (Gabrielsson, 2001), dan respons fisiologis terhadap musik berbeda tergantung pada jenis musik yang mereka dengarkan.
Penelitian tentang pengaruh sinyal musik individu pada komunikasi emosi tertentu dengan pendengar menyatakan bahwa sinyal musik yang paling efektif dan paling sering dipelajari adalah mode, tempo, dinamika, artikulasi, timbre, dan frase (Gabrielsson dan Lindstrom, 2010). Faktanya, parameter musik seperti tempo atau mode adalah karakteristik yang melekat dari struktur musik (van der Zwaag et al., 2011), yang diketahui mempengaruhi emosi pendengar. Preferensi musik sering diperlakukan sebagai keadaan afektif (Scherer dan Zentner, 2001) karena mereka sangat terkait dengan nilai (pengalaman positif atau negatif) (Istók, 2013). Selain itu, mengenali emosi dasar dalam musik, seperti kebahagiaan atau kesedihan, tidak mudah dan sangat konsisten pada orang dewasa (Peretz et al., 1998).

Dalam contoh bereksperimen dengan petunjuk musik, 20 pemain diminta untuk memanipulasi nilai-nilai tujuh variabel musik secara bersamaan (tempo, volume, artikulasi, frase, register, timbre, dan kecepatan serangan) untuk membuat lima ekspresi emosi yang berbeda (netral, bahagia, menakutkan, damai, sedih) untuk masing-masing dari empat skor (Bresin dan Friberg, 2011). Penelitian lain juga mengungkapkan bahwa ada sejumlah elemen dalam aspek suara yang mengubah respons emosional untuk mendengarkan musik (Glowinski dan Camurri, 2012). Elemen-elemen ini dikaitkan dengan fitur skor seperti pitch (tinggi / rendah), interval (pendek / panjang), harmoni (konsonan / disonan) dan ritme (teratur / tidak teratur). Dinamika antara elemen-elemen suara ini juga penting dan sangat tergantung pada interpretasi instrumental (atau fitur bermain), mis. Aksen berirama, artikulasi (staccato / legato), variasi timbre (kekayaan spektral, mode permainan, dll.). Dalam manipulasi isyarat musik yang sistematis, desain faktorial yang dioptimalkan dengan enam isyarat musik utama (mode, tempo, dinamika, artikulasi, timbre dan register) digunakan untuk empat contoh musik yang berbeda (Eerola et al., 2013). Dalam 10 tahun terakhir, banyak penelitian lain telah meneliti pengaruh tempo, sebagian besar dalam kombinasi dengan mode, pada respon afektif. Pendekatan interaktif untuk memahami respons emosional terhadap musik telah dibuat dengan memanipulasi tiga elemen 
musik secara bersamaan: mode, tekstur dan tempo (Webster dan Weir, 2005).

Seperti yang kita pahami, semua penelitian sebelumnya menunjukkan bahwa perlu bereksperimen dengan tempo dan unit ritmik untuk mengatur emosi melalui musik.

\section{RUMUSAN MASALAH}

1. Apakah musik dengan tempo yang berbeda mempengaruhi detak jantung?

2. Apakah pengalaman bermusik seorang musisi akan mempengaruhi persepsi musikalnya yang kemudian mempengaruhi detak jantung?

\section{A. PELAKSANAAN}

a. Lokasi Penelitian

Penelitian diadakan di ruangan studio musik Universitas Universal, Batam.

\section{b. Sampel Penelitian}

Sampel dalam penelitian ini adalah mahasiswa/i seni musik Universitas Universal yang mempunyai pengalaman yang cukup lama dalam bermusik klasik dan yang mempunyai pengalaman singkat dalam bermusik klasik.

Teknik pengambilan sampel yang digunakan dalam penelitian ini adalah dengan menggunakan teknik purposive sampling, jumlah sampel 2 responden.

Penentuan sampel dalam penelitian ini harus memenuhi kriteria inklusi sebagai berikut : dan musik dangdut. Adapun variabel terikat yaitu variabel yang diduga nilainya akan berubah karena pengaruh dari variabel bebas (Setiadi, 2007). Variabel terikat dalam penelitian ini adalah frekuensi denyut jantung.

Penelitian ini bersifat prospektif eksperimental sungguhan, bersifat komparatif dengan menggunakan rancangan pra-tes dan postes. Data diolah dalam bentuk grafik sehingga dapat terlihat kenaikan atau penurunan detak jantung pada saat pra-tes, pertengahan tes, dan pos-tes. Data yang didapat dikelola secara kuantitatif dan kualitatif. Sampel sebanyak 2 subjek, dengan teknik purposive sampling. Data yang dihitung berupa HR (Heart Rate) dalam satuan denyut/menit.

\section{HASIL DAN PEMBAHASAN}

Frekuensi detak jantung pra-tes,

pertengahan tes, dan pos-tes.

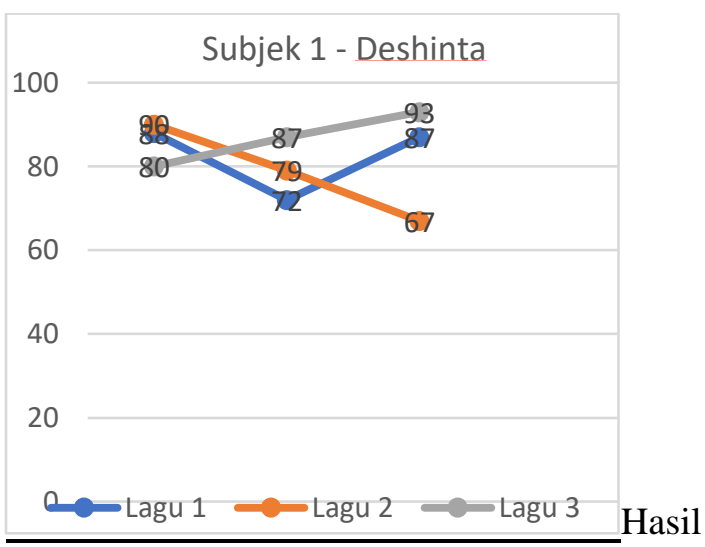

Tes Detak Jantung (Denyut/menit) Subjek 1
a. Subjek dalam keadaan sehat dan bugar.
b. Subjek tidak memiliki gangguan pendengaran

\section{B. METODE PENELITIAN}

Variabel dalam penelitian ini terdiri dari dua yaitu variabel bebas dan variabel terikat. Variabel bebas adalah variabel yang menyebabkan berubahnya nilai dari variabel terikat. (Setiadi, 2007). Variabel bebas dalam penelitian ini adalah tindakan pemberian musik klasik ( musik bertempo lambat dan cepat)

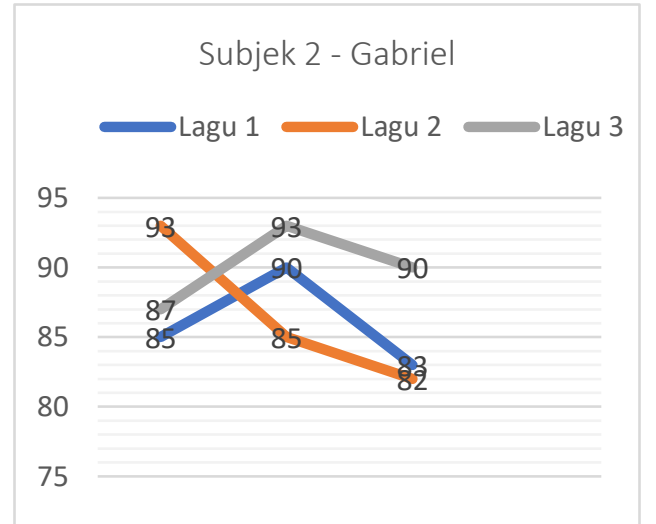

Hasil Tes Detak Jantung (Denyut/menit) Subjek 2 


\begin{tabular}{|c|c|c|c|c|c|c|}
\hline \multirow{2}{*}{$\begin{array}{l}\text { Frekuensi } \\
\text { Detak } \\
\text { Jantung } \\
\text { (Denyut/ } \\
\text { Menit) }\end{array}$} & \multicolumn{3}{|c|}{$\begin{array}{l}\text { Subjek } 1 \text { ( } \\
\text { Musisi } \\
\text { Amatir) }\end{array}$} & \multicolumn{3}{|c|}{$\begin{array}{l}\text { Subjek } 2 \text { ( } \\
\text { Musisi Non- } \\
\text { Amatir) }\end{array}$} \\
\hline & $\begin{array}{l}\mathrm{La} \\
\mathrm{gu} \\
1\end{array}$ & $\begin{array}{l}\mathrm{La} \\
\mathrm{gu} \\
2\end{array}$ & \begin{tabular}{|l}
$\mathrm{La}$ \\
$\mathrm{gu}$ \\
3
\end{tabular} & $\begin{array}{l}\mathrm{La} \\
\mathrm{gu} \\
1\end{array}$ & $\begin{array}{l}\mathrm{La} \\
\mathrm{gu} \\
2\end{array}$ & $\begin{array}{l}\mathrm{La} \\
\mathrm{gu} \\
3\end{array}$ \\
\hline Pra-Tes & 88 & 90 & 80 & 85 & 93 & 87 \\
\hline $\begin{array}{l}\text { Pertengah } \\
\text { an Tes }\end{array}$ & 72 & 79 & 87 & 90 & 85 & 93 \\
\hline Pos-Tes & 87 & 67 & 93 & 83 & 82 & 90 \\
\hline
\end{tabular}

Lagu 1 : Musik klasik (tempo cepat): The Phantom of The Opera - Prague Cello Quartet

Lahu 2 : Musik klasik (tempo lambat): Hadyn String Quartet No. 62 Op. 76 No. 3 "Emperor" (2 ${ }^{\text {nd }}$ Movement) - Veridis Quartet

Lagu 3 : Musik dangdut (Goyang Nasi Padang)

Hasil tes menunjukan adanya perbedaan grafik detak jantung pada musisi amatir dan musisi non-amatir. Perbedaan yang terdapat cukup signifikan melihat bahwa detak jantung subjek 1 (musisi amatir) cenderung meningkat pada akhir lagu yang cepat sedangkan subjek 2 (musisi non-amatir) cenderung menunjukan penurunan detak jantung di akhir lagu cepat.

Pada lagu pertama dimainkan Musik Klasik yang berjudul "The Phantom of The Opera - Prague Cello Quartet" yang merupakan musik bertempo cepat. Pada subjek 1 terjadi penurunan frekuensi detak jantung pada pertengahan lagu kemudian mengalami peningkatan setelah pertengahan sampai pada akhir lagu. Sedangkan subjek 2 mengalami peningkatan detak jantung pada pertengahan lagu dan penurunan detak jantung setelah pertengahan sampai dengan selesainya lagu.

Penelitian yang dilakukan oleh Livingstone, Muhlberger, Brown, dan Loch (2007) menunjukan beberapa elemen musik yang memiliki pengaruh terhadap munculnya emosi. Elemen yang paling berpengaruh adalah tempo diikuti dengan mode, volume, artikulasi, dan pitch.

Musik bertempo cepat menyebabkan otak manusia menghasilkan gelombang beta. Gelombang beta akan merangsang pengeluaran adrenalin ketika berpikir logis, merasakan stress atau tekanan. Ketika mendengarkan musik dengan tempo cepat, tubuh menghasilkan adrenalin juga 3 seperti halnya pada keadaan stres. Hal ini yang menyebabkan perangsangan simpatis lalu meningkatkan HR (Heart Rate) dan BP (Blood Pressure). (www.4mind4life.com, 2008).

Namun, dalam tes yang dilakukan kedua subjek cenderung mengalami detak jantung yang fluktuatif. Pada subjek 1 penurunan detak jantung pada pertengahan lagu ini bisa disebabkan oleh faktor-faktor lain selain elemen-elemen yang dikandung dalam musik itu sendiri, seperti kebosanan. Menurut Ardon Shorr Ph.D yang lulus di Universitas Oberlin College Majoring in Neuroscience \& Music Theory bahwa musik, musik klasik terutama dapat menyebabkan kebosanan pada para pendengarnya karena sulitnya otak dalam mencerna frase-frase pada musik tersebut ditambah dengan tidak adanya lirik dalam musik tersebut. Hal ini dapat terjadi pada kebanyakan masyarakat awam dan musisi amatir yang belum terbiasa mencerna musik klasik.

Pada tahap setelah pertengahan lagu sampai pada akhir lagu subjek 1 mengalami peningkatan frekuensi detak jantung. Dengan adanya peningkatan detak jantung pada subjek 1 dapat dilihat bahwa subjek 1 mulai dapat mencerna musik tersebut dengan menyelaraskan dan menerima gelombang-gelombang bunyi musik klasik cepat dengan terangsangnya kembali bagian motorik otak mengikuti peningkatan tempo, dinamika, dan volume dalam musik tersebut.

Pada subjek 2 terjadi sebaliknya. Peningkatan detak jantung terjadi pada pertengahan lagu dan penurunan detak jantung terjadi setelah pertengahan lagu sampai dengan akhir lagu. Hal ini menunjukan bahwa musisi non-amatir dapat langsung mencerna musik klasik tersebut karena adanya pengalaman dan 
pengertian yang lebih mendalam akibat pembelajaran yang lebih lama daripada musisi amatir. Dengan meningkatnya detak jantung dari awal hingga pertengahan lagu juga menunjukan bahwa subjek 2 dapat mengikuti tempo, dinamika, dan volume musik secara langsung. Namun, setelah pertengahan lagu menuju akhir lagu subjek 2 mengalami penurunan detak jantung. Ada beberapa hal yang dapat mempengaruhi hal tersebut yang pertama adalah ingatan episodik. Mekanisme ingatan episodik menjelaskan proses dimana emosi timbul pada pendengar karena musik mendatangkan ingatan pendengar pada sebagian peristiwa dalam kehidupannya. Penelitian ini menunjukan bahwa musik sering kali membangkitkan kenangan (Gabrielsson, 2001; Juslin dkk., 2006; Sloboda 1992).

Dalam wawancara yang dilakukan kepada subjek 2, ia mengatakan bahwa ia sudah pernah memainkan lagu klasik tersebut. Hal ini dapat membentuk kerangka tes ini bahwa munculnya kenangan-kenangan yang dibangkitkan oleh musik memungkinkan munculnya ekspektasi-ekspektasi musik yang dimana musisi sudah mengingat kembali kemana arah musik itu akan mengalun. Ingatan akan kelanjutan-kelanjutan musik tersebut dapat mengakibatkan mulai munculnya rasa bosan pada subjek 2 sehingga hal itu mengakibatkan penurunan detak jantung setelah pertengahan sampai pada akhir lagu.

Pada lagu kedua dimainkan lagu Hadyn String Quartet No. 62 Op. 76 No. 3 "Emperor" ( $2^{\text {nd }}$ Movement) - Veridis Quartet, yaitu lagu bertempo lambat. Kedua subjek mengalami penurunan detak jantung pada lagu kedua secara konsisten, tidak adanya kenaikan frekuensi pada detak jantung. Beberapa penelitian sudah dilakukan oleh sejumlah peneliti mengenai respon biologis manusia terhadap elemen musik terkhususnya tempo. Beberapa penelitian menyediakan investigasi yang lebih jauh mengenai mode dan tempo (Trochidis and Bigand, 2013). Mereka melakukan penelitian terhadap efek dari tiga mode (mayor,minor,Locrian) dan tiga tempo (lambat, sedang, cepat) dalam hal yang menyangkut emosi. Tempo memiliki efek yang lebih besar terhadap peningkatan dan penurunan emosi, tempo cepat lebih cenderung dihubungkan dengan emosi marah dan senang, sedangkan tempo lambat menimbulkan emosi yang lebih syahdu dan sedih. Hal ini mengacu kepada bahwa tempo mempengaruhi keadaan emosi seseorang.

Untuk lagu ketiga, Musik dangdut (Goyang Nasi Padang). Kedua subjek mengalami peningkatan, namun pada subjek 2 terjadi penurunan yang tidak begitu signifikan pada akhir lagu. Hasil tes pada lagu ketiga ini melahirkan ekstraksi informasi sementara dan interpretasi dalam hal emosi mempengaruhi fondasi biologis karena tempo berhubungan dengan domain-general property sinyal. Secara singkat, tempo cepat biasanya dihubungkan dengan peningkatan gairah. (Trehub et al., 2010). Melihat bahwa lagu yang dimainkan adalah lagu yang familiar dengan kedua subjek, menunjukan bahwa adanya pengertian dan hubungan yang terjalin langsung antara lagu dengan subjek.

Dengan tempo yang cepat, detak jantung kedua subjek menunjukan bahwa tubuh merespon secara langsung terhadap musik yang diperdengarkan dan dengan tempo yang relative cepat dan ber-ritme pendek ini berpengaruh pada penigkatan sistem kardiovaskular, yang salah satunya adalah detak jantung.

\section{KESIMPULAN}

Objektif dari penulisan ini adalah untuk melihat apakah adanya perbedaan respon terhadap musik oleh musisi amatir dan nonamatir. Penulisan ini berfokus kepada peningkatan dan penurunan detak jantung melalui beberapa parameter musik.

Dari hasil penelitian telah dipelajari bahwa elemen-elemen musik terkhususnya tempo sangat berpengaruh terhadap sistem kardiovaskuler manusia. Tempo yang menghasilkan gelombang otak secara khusus melalui kecepatannya juga dapat memberikan efek emosi tertentu terhadap manusia yan akan mempengaruhi biologis manusia tersebut.

Dalam kaitannya dengan keamatiran musisi. Dapat dilihat bahwa ada faktor penentu lain dalam hal reaksi biologis ini. Faktor tersebut 
adalah memori episodik, yaitu memori yang timbul pada pendengar karena musik mendatangkan ingatan pendengar pada sebagian peristiwa dalam kehidupannya. Munculnya ingatan ini akan mempengaruhi biologis manusia terkhususnya detak jantung yang merupakan respon dari otak tersebut.

\section{DAFTAR PUSTAKA}

Satria S. 2010. Eksperimen Mengenai Emosi Oleh Musik Bahagia Dan Sedih Dengan Volume Tertentu. Skripsi. Tidak Diterbitkan. Fakultas Psikologi. Universitas Sanata Dharma : Yogyakarta.

Winata, Joan Tania Cahya. 2008. Pengaruh Berbagai Tempo Musik Terhadap Denyut
Jantung. Other thesis, Universitas Kristen Maranatha : Bandung.

Fernandez, Sotos Alicia,dkk,2016. Influence of Tempo and Rhythmic Unit in Musical Emotion Regulation. Front Comput Neurosci. Agustus 2016; 10: 80

Pereira CS,dkk.2011. Music and Emotions in the Brain: Familiarity Matters. PLoS ONE 6(11): e27241.

Juslin PN, Sloboda JA (2001) Music and emotion: theory and research. New York: Oxford University Press. 504 p. 